\title{
Analysis of chloride transport and storage properties of high performance concrete modified by fly ash addition as an effective tool for assessment of its durability
}

\author{
Z. Pavlík, M. Pavlíková, L. Fiala, H. Benešová, \\ J. Mihulka \& R. Černý \\ Department of Materials Engineering and Chemistry, Faculty of Civil \\ Engineering, Czech Technical University in Prague, Czech Republic
}

\begin{abstract}
The effect of fly ash addition on moisture and chloride transport and storage properties of high performance concrete is studied. For comparative reasons, the samples of reference Portland cement concrete without fly ash are analyzed as well. A basic characterization of investigated materials is performed using determination of bulk density, matrix density and total open porosity. Chloride binding isotherms are measured by modified adsorption method. For the determination of chloride transport properties, two different experiments are performed. At first, the chloride transport is characterized by the water and chloride solution absorption coefficients resulting from the standard sorption test. In the second experiment, and moisture diffusivity as function of moisture content, and chloride diffusion coefficient as function of chloride concentration are calculated by inverse analysis. On the basis of obtained material parameters describing the moisture and salt transport and storage, the durability of fly ash modified high performance concrete is assessed and compared to reference material.
\end{abstract}

Keywords: high performance concrete, fly ash, chloride transport and storage.

\section{Introduction}

Portland cement based concrete is considered to be versatile material having high durability and utility properties. However, in severe climatic conditions, concrete 
structures show degradation of structural performance. Among the most aggressive environmental deteriorations that negatively affect the long-term durability and service life of concrete structures belong moisture and salts attack [1]. Negative effects of salt action can be basically divided into the following six mechanisms: chemical reaction of salts with concrete components, salt crystallization, enhanced hygroscopic water absorption, salt hydration, efflorescence and salt leaching, differential thermal expansion between salts and solid material of concrete matrix [2].

High performance concretes (HPC) are expected to possess better durability properties than common concrete, and their composition is based not only on Portland cement binder, but also supplementary cementitious materials (SCM) such as blast-furnace slag, fly ash, silica fume, metakaolin, and different types of natural pozzolana as a partial replacement of ordinary cement are admixed. These materials are currently highly attractive for concrete industry, because of environmental regulations for $\mathrm{CO}_{2}$ production that is in clear relation to cement production. The $\mathrm{CO}_{2}$ emissions from cement plants represent no less than $5 \%$ of total anthropogenic emissions [3, 4] despite the efforts of cement industry to reduce emissions. Recent studies on the life cycle assessment of concrete structures proved that $85 \%$ of the $\mathrm{CO}_{2}$ emissions are related to cement production [5].

Fly ash is probably the most often used SCM in concrete production worldwide, especially because it is available in large amounts for low price as by product of coal-burning thermal power stations. On that account, an intensive research on its application in concrete production and effect its admixture on concrete performance and properties was done. Many studies were devoted to the maximization of the amount of fly ash which could be safely used as SCM, aiming at the lower overall cost of concrete production (e.g. [6-8]). In spite of intensive research of fly-ash concrete, the attention was paid mainly to its mechanical performance, whereas the other material parameters were studied less frequently. In case of application of fly ash in lower-grade concretes, the complexity of studying material properties is often not necessary. On the other hand, for high performance concretes also the other material properties have to be investigated, among them for instance frost resistance, toughness, fire resistance, permeability, corrosion resistance, etc.

In this paper we have focused on the evaluation of the effect of fly ash addition on moisture and chloride transport and storage properties of high performance concrete as they represent important information for the evaluation of concrete resistivity against possible moisture and salt induced damage.

\section{Studied materials}

The HPC mixtures were prepared with Portland cement CEM I 42.5 R (Mokrá, Czech Republic) as the main binder having the specific surface area $341 \mathrm{~m}^{2} / \mathrm{kg}$ [9]. Its chemical composition is presented in Table 1. A part of Portland cement was replaced by fly ash produced by burning bituminous coal in thermal power plant Dětmarovice, Czech Republic. The chemical composition of applied fly 
ash is given in Table 2. The phase analysis showed the presence of quartz, mullite $3 \mathrm{Al}_{2} \mathrm{O}_{3} \cdot 2 \mathrm{SiO}_{2}$, hematite $\mathrm{Fe}_{2} \mathrm{O}_{3}, \mathrm{CaSO}_{4}$ anhydrite, anatase $\mathrm{TiO}_{2}$, and albite $\mathrm{NaAlSi}_{3} \mathrm{O}_{8}$. Details on grain size distribution of investigated fly ash can be found in [9].

Table 1: $\quad$ Chemical compositions of cement CEM I $42.5 \mathrm{R}$.

\begin{tabular}{|c|c|}
\hline Component & Amount [\% by mass] \\
\hline $\mathrm{SiO}_{2}$ & 58.7 \\
\hline $\mathrm{Al}_{2} \mathrm{O}_{3}$ & 38.5 \\
\hline $\mathrm{Fe}_{2} \mathrm{O}_{3}$ & 0.72 \\
\hline $\mathrm{CaO}$ & 0.20 \\
\hline $\mathrm{MgO}$ & 0.38 \\
\hline $\mathrm{K}_{2} \mathrm{O}$ & 0.85 \\
\hline $\mathrm{TiO}_{2}$ & 0.50 \\
\hline
\end{tabular}

Table 2: $\quad$ Chemical composition of fly ash.

\begin{tabular}{|c|c|}
\hline Component & Amount [\% by mass] \\
\hline $\mathrm{SiO}_{2}$ & 49.82 \\
\hline $\mathrm{Al}_{2} \mathrm{O}_{3}$ & 24.67 \\
\hline $\mathrm{Fe}_{2} \mathrm{O}_{3}$ & 7.05 \\
\hline $\mathrm{CaO}$ & 3.91 \\
\hline $\mathrm{MgO}$ & 2.68 \\
\hline $\mathrm{K}_{2} \mathrm{O}$ & 2.78 \\
\hline $\mathrm{Na}_{2} \mathrm{O}_{2}$ & 0.70 \\
\hline Sulphur - total as $\mathrm{SO}_{3}$ & 0.91 \\
\hline Sulphates as $\mathrm{SO}_{3}$ & 0.34 \\
\hline
\end{tabular}

Table 3: $\quad$ Composition of studied HPCs.

\begin{tabular}{|c|c|c|}
\hline Component & $\mathrm{CR}$ & CFA \\
\hline & \multicolumn{2}{|c|}{ Amount $\left[\mathrm{kg} / \mathrm{m}^{3}\right]$} \\
\hline CEM I 42.5 R & 484 & 440 \\
\hline Siliceous sand $0-4 \mathrm{~mm}$ & 812 & 812 \\
\hline Siliceous aggregates $8-16 \mathrm{~mm}$ & 910 & 910 \\
\hline $\begin{array}{l}\text { Superplasticizer Mapei Dynamon } \\
\text { SX }\end{array}$ & 5.3 & 5.3 \\
\hline Fly ash & - & 44 \\
\hline Batch water & 148 & 137 \\
\hline
\end{tabular}

The composition of studied HPCs is given in Table 3. In both materials, the superplasticizer Mapei Dynamon SX originally developed for high-quality transport concrete was applied for reduction of water/binder ratio. The used total mass of binder in the reference mix CR was the same as in CFA. The amount of water in the mixtures was chosen in such a way that the consistence of fresh mixtures would be the same. The consistence was analyzed using the slump test according to Czech European standard ČSN EN 12350-2 [9, 10], using a conical 
mould. The result of the slump test (in $\mathrm{mm}$ ) was the difference between the height of the mould and the uppermost point of the specimen after the test. For both investigated concretes, the measured slump was $130 \mathrm{~mm}$.

The samples of tested mixtures were cast into the steel moulds having specific dimensions according to the planned experiments. After one day, the samples were unmoulded, and cured at high humidity environment for 28 days. Then, samples for measurement moisture and chloride transport properties of studied HPCs using two different suction experiments were cut from the cast beams. The dimensions of these samples were $40 \times 40 \times 20 \mathrm{~mm}$ for standard sorption experiment, and $20 \times 40 \times 200 \mathrm{~mm}$ for moisture and chloride concentration profiles measurement in 1-D arrangement of the uptake experiment. Samples for measurement of chloride binding isotherms with the dimensions of $20 \times 20 \times 10$ $\mathrm{mm}$ were also prepared using the same procedure. For measurement of basic material properties, the specimens of dimensions $40 \times 40 \times 20 \mathrm{~mm}$ were used.

\section{Experimental methods}

For the basic characterisation of studied materials, bulk density and matrix density were measured at first. Bulk density was determined from the measurement of sample sizes using digital length meter and its dry mass. The matrix density was accessed by helium pycnometry using apparatus Pycnomatic ATC. The accuracy of the gas volume measurement using this device was \pm $0.01 \%$ from the measured value, whereas the accuracy of used analytical balances was $\pm 0.0001 \mathrm{~g}$. On the basis of these measurements, the total open porosity was calculated. The accuracy of basic material properties measurement was $\pm 10 \%$.

For determination of material characteristics describing the coupled moisture and chloride transport, two different experiments were performed. In the first experiment, the moisture and chloride ions transport was analyzed using the free water or $\mathrm{NaCl}$ water solution of chosen concentration intake experiment. In this way, the transport of liquid water and chloride ions was described by sorptivity and water absorption coefficient. The sorptivity $S\left(\mathrm{~m} / \mathrm{s}^{1 / 2}\right)$, according to original work by Hall [11], is defined as

$$
I=S \cdot t^{1 / 2},
$$

where $I(\mathrm{~m})$ is the cumulative absorption of water (resp. salt solution) and $t(\mathrm{~s})$ the corresponding time.

The water absorption coefficient $A_{w}\left(\mathrm{~kg} / \mathrm{m}^{2} \mathrm{~s}^{1 / 2}\right)$ can be calculated by multiplying the sorptivity by the density of water $\rho_{w}\left(\mathrm{~kg} / \mathrm{m}^{3}\right)$. In an analogous way, the chloride water solution absorption coefficient $A_{c h}\left(\mathrm{~kg} / \mathrm{m}^{2} \mathrm{~s}^{1 / 2}\right)$ is obtained as a product of sorptivity and density of $\mathrm{NaCl}$ water solution of specific concentration $\rho_{c h}\left(\mathrm{~kg} / \mathrm{m}^{3}\right)$.

The experimental setup for the absorption experiment performed in this paper consisted of tank with liquid, and the specimen, water and vapour-proof insulated on four lateral sides, hanged on the automatic digital balances and immersed 1-2 $\mathrm{mm}$ in the penetrating liquid. Using automatic balances allows 
recording the increase of mass. The constant liquid level in tank is maintained by Mariotte's bottle. In this way, continuous intake of penetrating liquid is ensured. Liquid absorption coefficient $A$ is calculated from the linear part of the dependence of the increase of tested sample mass $\left(\mathrm{kg} / \mathrm{m}^{2}\right)$ on the square root of time $\left(\mathrm{s}^{1 / 2}\right)$. The original procedure of the absorption experiment is described in more detail in $[12,13]$.

Within the absorption experiments performed in this work, the samples were insulated using epoxy resin and dried at $60^{\circ} \mathrm{C}$. As penetrating medium, $\mathrm{NaCl}$ water solutions having concentration $5 \%$ (density $1034 \mathrm{~kg} / \mathrm{m}^{3}$ ) and $15 \%$ (density $1109 \mathrm{~kg} / \mathrm{m}^{3}$ ) were used. Also the penetration of pure distilled water was investigated (density $998 \mathrm{~kg} / \mathrm{m}^{3}$ ). The measurements were performed on five samples for each penetrating medium. The accuracy of obtained results was approximately $\pm 20 \%$ from measured values, especially taking into account the inhomogeneity of studied HPC samples.

In the second experiment, the measurement of moisture and chloride ions' concentration profiles was performed. The experiments were done in the conditions of one-sided $1.0 \mathrm{M} \mathrm{NaCl}$ solution vertical uptake into the samples of investigated HPCs. At first, the lateral sides of the samples were water and vapour-proof insulated by epoxy resin and dried at $60^{\circ} \mathrm{C}$. Then the samples were put in contact with $5 \% \mathrm{NaCl}$ water solution and after chosen time interval (24 hours, 24 days, 71 days) cut into several pieces $20 \mathrm{~mm}$ thick. From the particular pieces was at first removed the insulating layer of epoxy resin and in each piece, the moisture content and chloride concentration were measured. In this way, the moisture and chloride concentration profiles for specific times of liquids penetration were obtained. The moisture content was accessed on gravimetric principle using the drying of the samples' fragments at $110^{\circ} \mathrm{C}$ to constant weight. For determination of chloride concentration, the dried samples were placed into the plastic vessels and overflowed by $200 \mathrm{ml}$ of hot distilled water. The samples in water-proof vessels were leached for two weeks at laboratory temperature $25 \pm 2{ }^{\circ} \mathrm{C}$. The chloride concentration in leaches was then measured using liquid chromatography. The measuring apparatus consisted of CHROM SDS containing vacuum pump and Injection Kit MIK 010 with valve Rheodyne $775 \mathrm{i}$ for accurate and reproducible dosing of liquid samples. The studied sample leaches were dosed using $10 \mu \mathrm{l}$ hypo Hamilton through the filter disk. WATREX detecting column was used for chloride ions monitoring. The liquid chromatography is considered one of the most precise methods for the ions' concentration measurement in water solutions, its absolute error is $2 \%$ from measured value.

The chloride binding capacity of tested materials was characterised using measurement of chloride binding isotherms that express dependence of the amount of bound chloride ions $C_{b C l}\left(\mathrm{~kg} / \mathrm{m}^{3}\right)$ in the material on the free chloride ion concentration $C_{f C l}\left(\mathrm{~kg} / \mathrm{m}^{3}\right)$ in the pore solution in equilibrium conditions. These measurements were done using modified absorption method proposed by Jiřičková and Černý [14]. Within the measurements, the dry samples were placed into the cups with $200 \mathrm{ml}$ chloride solution. Then they were stored in laboratory at the temperature of $22 \pm 2^{\circ} \mathrm{C}$ to reach equilibrium. The inside solutions were 
analyzed after 4 months, the concentration of chlorides was measured using chloride selective electrodes and measuring device $\mathrm{pH} / \mathrm{ION}$. From the obtained data the bound chloride content was calculated and chloride binding isotherms were plotted.

\section{Computational identification of moisture diffusivity and chloride diffusion coefficient}

For calculation of moisture dependent moisture diffusivity and concentration dependent chloride diffusion coefficient of studied HPCs, inverse analysis of experimentally measured moisture and chloride concentration profiles was done. There is fundamental for inverse analysis to formulate the mathematical model of coupled moisture and salt transport. In this paper we have used for description of $\mathrm{NaCl}$ water solution transport a modified diffusion-advection model originally formulated by Bear and Bachmat [15]. In this model, the transport of salt solution was described by the salt mass balance

$$
\frac{\partial\left(w C_{f C l}\right)}{\partial t}=\operatorname{div}\left(w D \operatorname{grad} C_{f C l}\right)+\operatorname{div}\left(C_{f C l} \kappa \operatorname{grad} w\right)-\frac{\partial C_{b C l}}{\partial t},
$$

and water mass balance

$$
\frac{\partial w}{\partial t}=\operatorname{div}(\kappa \operatorname{grad} w)
$$

where $C_{f C l}\left(\mathrm{~kg} / \mathrm{m}^{3}\right)$ is the concentration of free chlorides in water, $C_{b C l}\left(\mathrm{~kg} / \mathrm{m}^{3}\right)$ the concentration of bonded salts in the whole porous body, $D\left(\mathrm{~m}^{2} / \mathrm{s}\right)$ the salt diffusion coefficient, $\kappa\left(\mathrm{m}^{2} / \mathrm{s}\right)$ the moisture diffusivity, $w\left(\mathrm{~m}^{3} / \mathrm{m}^{3}\right)$ the volumetric moisture content.

System of equations (2) - (3) can be subjected to an inverse analysis in a similar way as for one parabolic equation, provided the initial and boundary conditions are simple enough, and the material parameters $D$ and $\kappa$ can be identified as functions of water content and salt concentration. About the details of inverse analysis procedure and mathematical operations we have already reported in several publications (e.g. in [16-18]). Therefore we here introduce only final formulas for calculation concentration dependent chloride diffusion coefficient

$$
D\left(z_{0}\right)=-\frac{C_{f}\left(z_{0}\right) \kappa\left(z_{0}\right)\left(\frac{d w}{d z}\right)_{z_{o}}}{w\left(z_{0}\right)\left(\frac{d C_{f}}{d z}\right)_{z_{o}}}+\frac{\int_{z_{0}}^{\infty} z\left(\frac{d\left(w C_{f}\right)}{d z}+\frac{d C_{b}}{d C_{f}} \frac{d C_{f}}{d z}\right) d z}{2 t_{0} \cdot w\left(z_{0}\right) \cdot\left(\frac{d C_{f}}{d z}\right)_{z_{0}}},
$$

and moisture dependent moisture diffusivity

$$
\kappa\left(z_{0}\right)=\frac{1}{2 t_{0}\left(\frac{d w}{d z}\left(z_{0}\right)\right)} \cdot \int_{z_{0}}^{\infty}\left(z \frac{d w}{d z}\right) d z
$$


where $z=$ the space variable, $t_{0}=$ the time corresponding to the chosen moisture and concentration profiles $w=w\left(z, t_{0}\right), C_{f}=C_{f}\left(z, t_{0}\right)$, the chosen values of moisture and concentration are $w_{0}=w\left(z_{0}, t_{0}\right), C_{f 0}=C_{f}\left(z_{0}, t_{0}\right)$, the corresponding moisture diffusivity and chloride diffusion coefficient $\kappa\left(z_{0}\right)=\kappa\left(w_{0}, C_{f 0}\right), D\left(z_{0}\right)=$ $D\left(w_{0}, C_{f 0}\right)$ and $C_{b}=f\left(C_{f}\right)$ is the chloride binding isotherm. These equations were derived using Boltzmann-Matano treatment applying two Boltzmann transformations.

\section{Results and discussion}

The measured basic material properties are given in Table 4 . We can see that the measured material characteristics were for both studied materials very similar. Their differences practically lied in the range of accuracy of applied measuring techniques.

Table 4: $\quad$ Basic material properties of investigated HPCs.

\begin{tabular}{|c|c|c|c|}
\hline Concrete & $\begin{array}{c}\text { Bulk density } \\
\left(\mathrm{kg} / \mathrm{m}^{3}\right)\end{array}$ & $\begin{array}{c}\text { Matrix density } \\
\left(\mathrm{kg} / \mathrm{m}^{3}\right)\end{array}$ & $\begin{array}{c}\text { Total open porosity } \\
(\%)\end{array}$ \\
\hline CR & 2380 & 2715 & 12.3 \\
\hline CFA & 2356 & 2717 & 12.5 \\
\hline
\end{tabular}

Measured values of liquid absorption coefficient and sorptivity are presented in Tables 5-7.

Table 5: $\quad$ Results of absorption experiment I.

\begin{tabular}{|c|c|c|}
\hline Mixture & $\begin{array}{c}\text { Absorption coefficient of } \\
\text { distilled water } \\
{\left[\mathrm{kg} / \mathrm{m}^{2} \mathrm{~s}^{1 / 2}\right]}\end{array}$ & $\begin{array}{c}\text { Sorptivity of } \\
\text { distilled water } \\
{\left[\mathrm{m} / \mathrm{s}^{1 / 2}\right]}\end{array}$ \\
\hline CR & 0.0125 & $1.252 \cdot 10^{-5}$ \\
\hline CFA & 0.0115 & $1.152 \cdot 10^{-5}$ \\
\hline
\end{tabular}

Table 6: $\quad$ Results of absorption experiment II.

\begin{tabular}{|c|c|c|}
\hline Mixture & $\begin{array}{c}\text { Absorption coefficient of } \\
5 \% \mathrm{NaCl} \text { solution } \\
{\left[\mathrm{kg} / \mathrm{m}^{2} \mathrm{~s}^{1 / 2}\right]}\end{array}$ & $\begin{array}{c}\text { Sorptivity of } 5 \% \\
\mathrm{NaCl} \text { solution } \\
{\left[\mathrm{m} / \mathrm{s}^{1 / 2}\right]}\end{array}$ \\
\hline CR & 0.0072 & $6.963 \cdot 10^{-6}$ \\
\hline CFA & 0.0072 & $6.963 \cdot 10^{-6}$ \\
\hline
\end{tabular}

Table 7: $\quad$ Results of absorption experiment III.

\begin{tabular}{|c|c|c|}
\hline Mixture & $\begin{array}{c}\text { Absorption coefficient of } \\
15 \% \mathrm{NaCl} \text { solution } \\
{\left[\mathrm{kg} / \mathrm{m}^{2} \mathrm{~s}^{1 / 2}\right]}\end{array}$ & $\begin{array}{c}\text { Sorptivity of } 15 \% \\
\mathrm{NaCl} \text { solution } \\
{\left[\mathrm{m} / \mathrm{s}^{1 / 2}\right]}\end{array}$ \\
\hline CR & 0.0066 & $5.951 \cdot 10^{-6}$ \\
\hline CFA & 0.0071 & $6.402 \cdot 10^{-6}$ \\
\hline
\end{tabular}


The absorption coefficients and sorptivities revealed the differences in the rate of pure water and salt solutions transport. The transport parameters were for water imbibition systematically higher than the values measured for transport of $5 \%$ and $15 \% \mathrm{NaCl}$ water solutions. This feature is probably the consequence of higher viscosity and density of salt solutions in comparison with pure distilled water. From the measured data, there is no evident and remarkable effect of fly ash addition on the moisture and salt solution propagation in studied HPC. Only in case of penetration of $15 \% \mathrm{NaCl}$ solution, the transport parameters of CFA were slightly higher than the values measured for reference HPC. However, taking into account the assumed error of applied measuring technique $( \pm 20 \%)$, and inhomogeneity of studied materials, the differences between the values of transport parameters determined for both studied HPCs were more or less negligible.

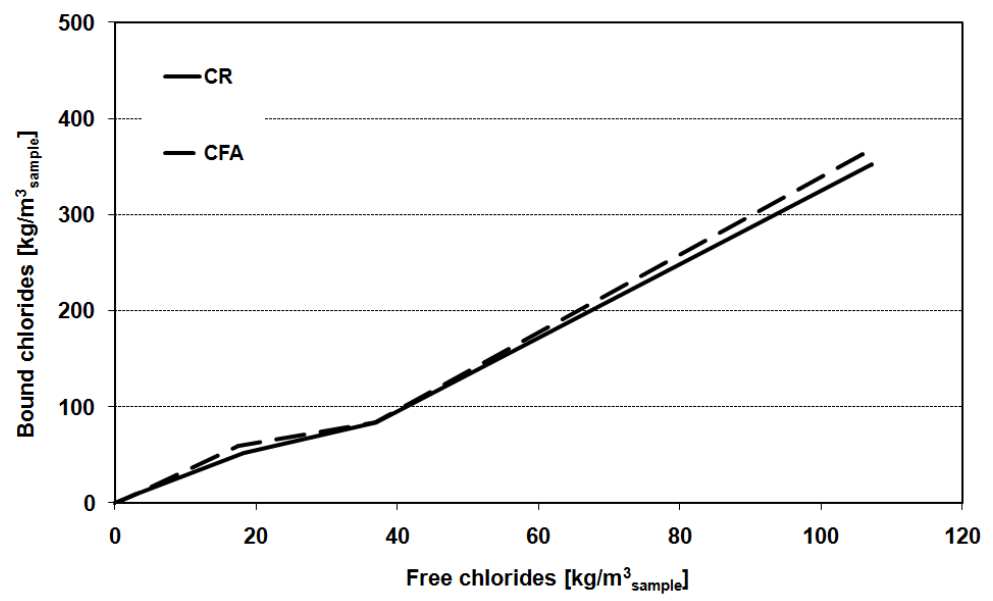

Figure 1: Chloride binding isotherms of studied HPCs.

Chloride binding isotherms are presented in Figure 1. Also in this experiment was the performance of both studied concretes similar, especially taking into account the accuracy of modified absorption method of binding isotherms measurement that was $\pm 10 \%$.

The moisture and corresponding salt concentration profiles measured for penetration of $5 \% \mathrm{NaCl}$ water solution are presented in Figures 2, 3. Looking at these data we can see that the moisture transport was in the case of concrete with fly ash faster than in the reference material. These results are contrary to the data measured for liquid absorption coefficient and sorptivity. On the other hand, the time of the absorption experiment was much shorter than the time of experiments for measurement of moisture and chloride concentration profiles. Therefore, the effect of fly ash addition on moisture and solution transport was not revealed within the simple absorption experiment. Since the moisture transport was in the both studied HPCs rather slow, long time duration of absorption experiment was necessary for a reliable assessment of their moisture and salt transport properties. 


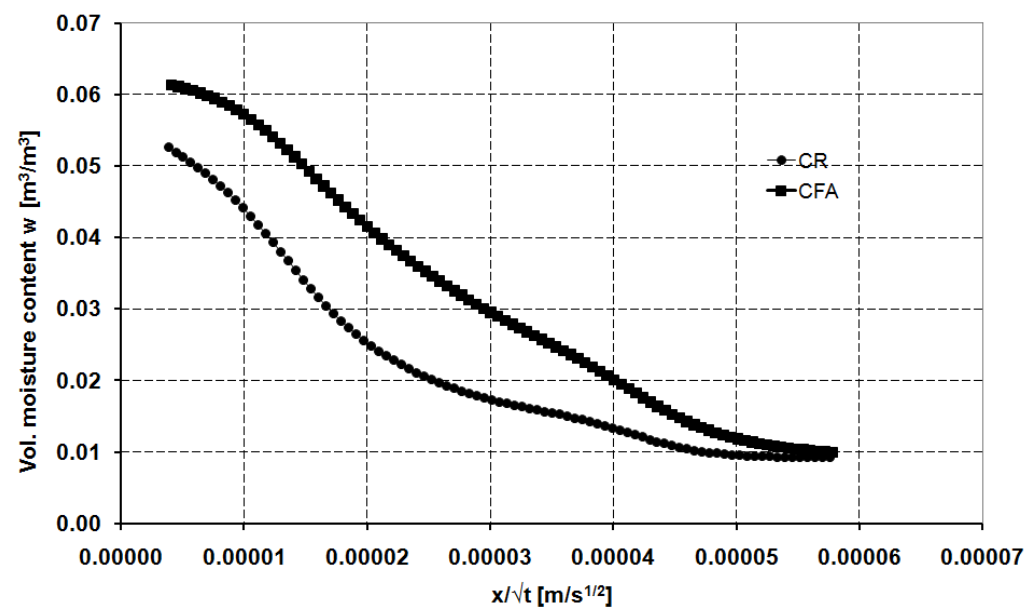

Figure 2: $\quad$ Moisture profiles measured for penetration of $5 \% \mathrm{NaCl}$ water solution.

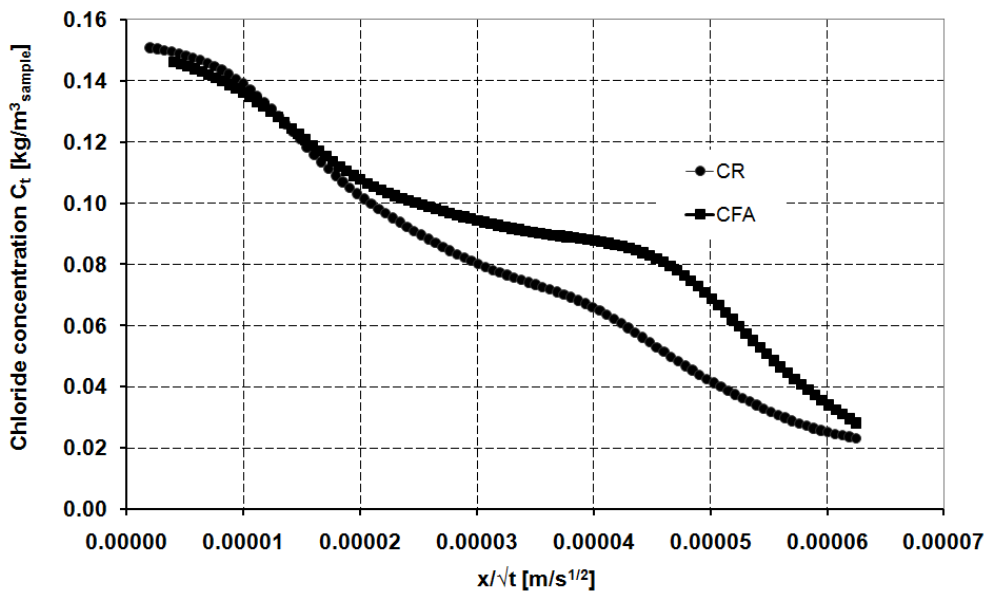

Figure 3: Total chloride concentration profiles.

Transport of chloride ions was for both studied materials similar and also very slow.

Moisture dependent moisture diffusivity of studied materials is presented in Figure 4. The values of moisture diffusivity were very low, what clearly documents the good resistivity of both materials against moisture and salt solution penetration. The chloride diffusion coefficients are given in Figure 5. These data indicate slightly slower chloride transport in CFA in comparison to reference HPC. 


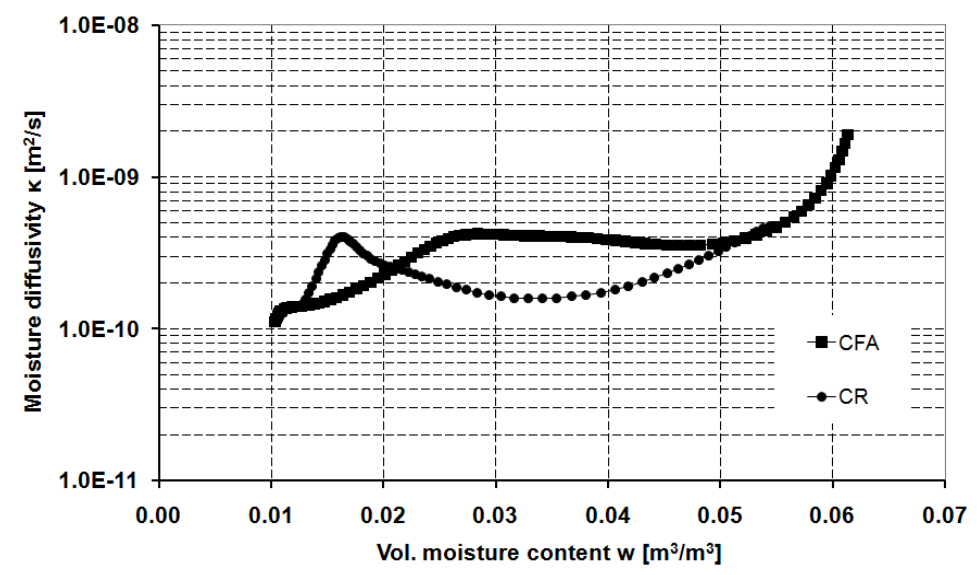

Figure 4: $\quad$ Moisture dependent moisture diffusivity of studied HPCs.

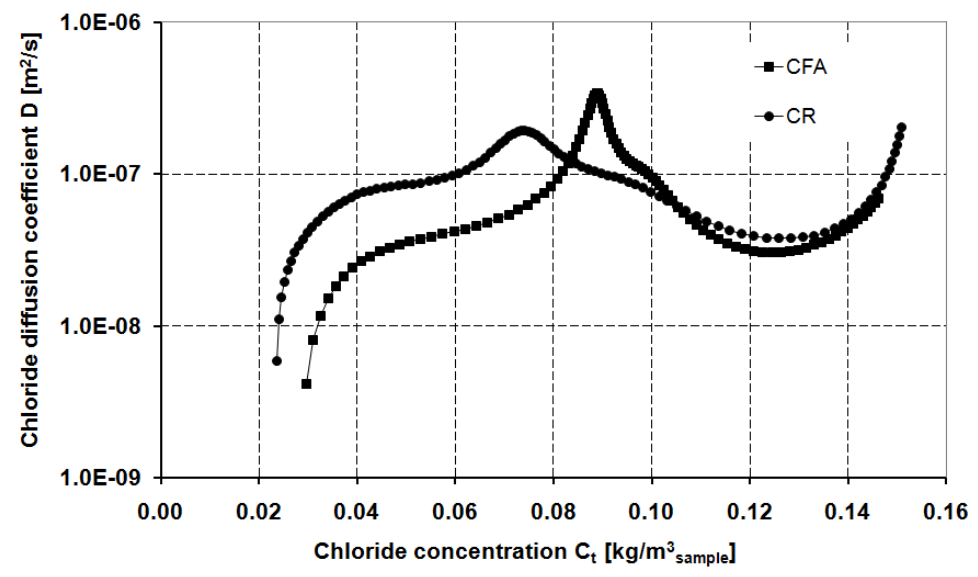

Figure 5: Chloride diffusion coefficient of studied HPCs.

\section{Conclusions}

Experimental and computational analysis of the effect of fly ash addition on moisture and chloride transport and storage properties of HPC was done in the paper. We have found out that the addition of fly ash had not significant effect on concrete ability to transport moisture and salt solutions in chosen concentrations. This finding corresponds to the results of total open porosity measurement, which remained more or less the same as in the case of reference concrete. The moisture transport was slightly faster in HPC with fly ash but in absolute numbers its moisture and chloride transport properties were very low. 
On this account, one can assume the sufficient durability of fly ash modified HPC concrete. In [9] we referred about mechanical properties of fly ash HPC. The compressive and bending strength of fly ash concrete after 28 days were slightly worse as compared with reference Portland cement concrete but the secondary pozzolanic reaction might lead to improvements in long-term view. Therefore, the fly ash has proved its applicability in concrete mix design. From the practical point of view, application of fly ash as partial replacement of Portland cement represents economical benefits for concrete producers. Indispensable is also the environmental impact of partial Portland cement replacement on $\mathrm{CO}_{2}$ production.

\section{Acknowledgement}

This research has been supported by the Ministry of Education, Youth and Sports of Czech Republic, under project No MSM: 6840770031.

\section{References}

[1] Illston, J.M. \& Domone, P.L.J., (eds). Construction Materials - Third Edition, Spon Press, Taylor and Francis Group: New York, 2007.

[2] Pavlík, Z., Identification of parameters describing the coupled moisture and salt transport in porous building materials, CTU: Prague, 2009.

[3] Brand, R., Pulles, T., Van Gilswijk, R., Fribourg-Blanc, B. \& Coubert, C., European pollutant emission register, Final report, 2004, www.eper.cec.eu.int.

[4] Habert, G. \& Rouseel, N., Study of two concrete mix-design strategies to reach carbon mitigation objectives. Cement and Concrete Composites, $\mathbf{3 1}$, pp. 397-402, 2009.

[5] Parrott, L. Cement, concrete and sustainability. A report on the progress of the UK cement and concrete industry towards sustainability, British Cement Association, 2002.

[6] Khatib, J.M., Performance of self-compacting concrete containing fly ash. Construction and Building Materials, 22, pp. 1963-1971, 2008.

[7] Dinakar, P., Babu, K.G. \& Santhanam, M., Durability properties of high volume fly ash self compacting concrete. Cement and Concrete Composites, 30, pp. 880-886, 2006.

[8] Kumar, B., Tike, G.K. \& Nanda, P.K. Evaluation of properties of highvolume fly-ash concrete for pavements. Journal of Materials in Civil Engineering, 19, pp. 906-911, 2007.

[9] Vejmelková, E. Pavlíková, M., Keppert, M., Keršner, Z., Rovnaníková, P., Ondráček, M., Sedlmajer, M. \& Černý, R., Fly ash influence on the properties of high performance concrete. Cement Wapno Beton, 13/75, pp. 189-204, 2009

[10] CSN EN 12350-2, Testing of fresh concrete - Part 2: Slump test. Czech Standardization Institute: Prague, 2000. 
[11] Hall, C., Water Sorptivity of Mortars and Concretes: A Review. Magazine of Concrete Research, 41, pp. 51-161, 1989.

[12] Jiřičková, M., Application of TDR Microprobes, Minitensiometry and Minihygrometry to the Determination of Moisture Transport and Moisture Storage Parameters of Building Materials, CTU: Prague, 2004.

[13] Roels, S., Carmeliet, J., Hens, H., Adan, O., Brocken, H., Černý, R., Pavlík, Z., Hall, C., Kumaran, K., Pel, L. \& Plagge, R.: Interlaboratory Comparison of Hygric Properties of Porous Building Materials. Journal of Thermal Envelope and Building Science, 27, pp. 307-325, 2004.

[14] Jiřičková, M. \& Černý, R., 2006. Chloride binding in building materials. Journal of Building Physics, 29, pp. 189-200, 2006.

[15] Bear, J. \& Bachmat, Y., Introduction to Modelling of Transport Phenomena in Porous Media, Vol. 4, Kluwer: Dordrecht, 1990.

[16] Pavlík, Z., Michálek, P., Pavlíková, M., Kopecká, I., Maxová, I. \& Černý R. Water and Salt Transport and Storage Properties of Mšené Sandstone. Construction and Building Materials, 22, pp. 1736-1748, 2008.

[17] Černý, R., Pavlík, Z. \& Rovnaníková, P., Experimental Analysis of Coupled Water and Chloride Transport in Cement Mortar. Cement and Concrete Composites, 26, pp. 705-715, 2004.

[18] Pavlík, Z., Tesárek, P., Maděra, J., Rovnaníková, P. \& Černý, R., Determination of Moisture Diffusivity and Salt Diffusion Coefficient of Building Materials. Acta Agrophysica, 6, pp. 773-783, 2005. 